\title{
Entrepreneurial Characteristics Amongst Different Professional Backgrounds: Evidence from Indonesia
}

\author{
Frangky Selamat ${ }^{1}$, Hetty Karunia Tunjungsari ${ }^{2 *}$, \\ Chairy $^{3}$, Didi Widya Utama ${ }^{4}$ \\ 124 Tarumanagara University, DKI Jakarta 11440, Indonesia \\ 3 President University, Jawa Barat 17550, Indonesia
}

\begin{abstract}
A B S T R A C T
The primary objective of this study is to examine the evidence of entrepreneurial characteristics amongst different professional backgrounds, both entrepreneurs and non-entrepreneurs, especially private employees, government employees, police officers, and entrepreneurs. We examined entrepreneurial characteristics in terms of innovativeness, need for achievement, locus of control, risk taking propensity, tolerance for ambiguity, and self-confidence. The sample in this study is 269 individuals who work as entrepreneurs, police officers, government employees and private employees in major cities in Indonesia areas. Research hypothesis testing were performed using ANOVA statistical tests and were proceeded using IBM SPSS Statistics software version 21. There are six hypotheses proposed in this study and all proposed hypothesis were statistically supported. In other words, there are significant differences in the average value of entrepreneurial characteristics being assessed, among police officers, government employees, private employees, and entrepreneurs. Theoretically, this study will hopefully contribute in invigorating previous studies which provide the evidence of different entrepreneurial characteristics between entrepreneurs and non-entrepreneurs. Practically, the implications of this study can provide suggestions in the personal development in a variety of jobs, especially in terms of entrepreneurial characteristics development. Entrepreneurial characteristics amongst active employees can generate organizational performance improvement. As for the retired employees, entrepreneurial characteristics will be a valuable source in starting a business activity.
\end{abstract}

ART I CLE INFO

Entrepreneurial Characteristics, Entrepreneur v.s. non-Entrepreneur, Professions.
*Correspondent Email: hettyt@fe.untar.ac.id 


\section{INTRODUCTION}

Statistics in Indonesia in February 2016 reported that unemployment rate amounted up to $5.5 \%$ of the total 118 million workforce. One of the causes of high unemployment rate was the gap between the economic growth and the level of labor force availability. Therefore, there is a substantial need to increase the number of jobs to reduce unemployment rate in Indonesia. New job creation through the formation of new businesses by entrepreneurs will help absorb the workforce which will finally contribute to the economic welfare improvement of the community at large.

According to Statistics, the number of entrepreneurs in Indonesia is about $1.56 \%$ of the population. This number is relatively small compared with several other countries such as Singapore which has 7\% entrepreneurs of the total population, Malaysia (5\%) and the United States $(12 \%)$. In pursuit of improving the nation's economy, Indonesia certainly needs to increase the number of entrepreneurs. However, becoming an entrepreneur is not easy and not everyone has the unique characteristics that support their entrepreneur life. To become successful, entrepreneur needs entrepreneurial skills such as self confidence, need for achievement, risk taking propensity, tolerance for ambiguity, internal locus of control dan innovativeness.

Entrepreneurial characteristics can be something embedded within an entrepreneur as well as can also be developed through education and training. Through diverse entrepreneurship education and workshop, one can learn how to develop entrepreneurial characteristics and apply them to succeed in running a business. Employees who wants to start their business in the future can also equip themselves with the skills and develop specific characteristics of entrepreneurs.

This study aims to examine the evidence of entrepreneurial characteristics amongst different professional backgrounds, both entrepreneurs and non-entrepreneurs, especially private employees, government employees, police officers, and entrepreneurs. The results of this study are expected to provide a description of the possibility of these professionals to become entrepreneurs in the future. The results are also expected to contribute to the entrepreneurship literature, preparing or debriefing retirement program, and a feedback to various institutions to increase the number of entrepreneurs and job creation in Indonesia.

\section{LITERATURE REVIEW}

\section{Entrepreneurial Characteristics}

According to Koh (1996), entrepreneurial characteristic consists of six basic components: innovativeness, need for achievement, locus of control, risk taking propensity, tolerance for ambiguity, and self confidence. These characteristics are well attached to successful entrepreneurs and can be developed by people who want to become successful entrepreneurs in the future.

Innovation is defined as an activity that includes the creation of a new product or a new quality, the creation of new production methods, entering new markets, creating new sources of supply, or creating a new structure within the organization or business (Gurol \& Atsan, 2006). Innovativeness is the starting point for entrepreneurial activities and the essential characteristic of entrepreneurship (Koh, 1996). Entrepreneurship literature shows that an entrepreneur is generally more innovative compared to a non-entrepreneur (Hisrich et al, 2012).

In his Motivation Theory, McClelland stated that the need for achievement is a strong psychological motivating factor behind a person's actions and has long been known as the factor that influence entrepreneurial behavior. Individuals with a high need for achievement have a strong desire to succeed and as a consequence will have entrepreneurial behavior (Koh, 1996). Previous studies showed that entrepreneurs' need for achievement is higher compared to the nonentrepreneurs'.

Personality variables associated with general expectations of one's ability to control events in the 
life are known as locus of control. Individuals with an internal locus of control believe that they are able to control events in life, while individuals with an external locus of control believe that events in life are the result of external factors, such as chance, luck, or fate (Koh, 1996). A number of empirical research supports that internal locus of control is an entrepreneurial characteristic (Koh, 1996; Hansemark, 1998).

The orientation of someone to capture the opportunities in the context of an uncertain decision making is referred to as risk-taking propensity (Koh, 1996). Situations of risk taking are inevitable in entrepreneurship activities. In an uncertain environment, entrepreneurship also includes risks related to financial stability, career opportunities, family relationships, emotional and psychological conditions. In general, groups with entrepreneurship activity which is related to risk-taking propensity are more prominent than the other groups (Gurol \& Atsan, 2006).

When a person is faced with the condition of the formation of structures with incomplete information, the person is considered to be in an ambiguous situation. The behavior of someone who receives an ambiguous situation and organizes the available information to solve it reflects the nature of tolerance for ambiguity (Koh, 1996). Someone who has a high tolerance for ambiguity is someone who considers ambiguous situations challenging and struggling to cope with the unstable and unpredictable situation for the sake of a good performance (Koh 1996).

Finally, self-confidence is also an important entrepreneurial characteristic and is associated with other psychological characteristics, such as internal locus of control, propensity to take risks and a tolerance for ambiguity (Koh,1996).

\section{Entrepreneurial Characteristics and Professions}

Researches on the entrepreneurial characteristics possessed by people with various professions are still limited. The majority of research works in the identification of entrepreneurial characteristics were mostly done on a group of entrepreneurs itself
(Sarri \& Trihopoulou, 2005; Thompson, 2004; Korunka, Frank, Luegler, and Mugler, 2003, Louw, van Eeden, Bosch, and Venter, 2003; Entrialgo, FernaAndez, \& VaAzquez, 2000) as well as students at undergraduate and graduate levels (Yusof, Sandhu, \& Jain, 2007; Gurol \& Atsan, 2006; Koh, 1996; Ho \& Koh, 1992). However, there were a number of studies that measured Entrepreneurial Attitude Orientation (EAO) score within individuals from various professions.

EAO is a scale developed by Robinson et al (1991) which can be used to identify differences in the skills of entrepreneurs and non-entrepreneurs using a score of achievement, self-esteem, personal control and innovation. Researches on the comparison of EAO among the various professions were conducted in the sales force, administrative staff, engineers, and managers of companies (Boshoff \& Scholtz, 1995; Hoole \& Boshoff, 1997; Kruger, Van Wyk \& Boshoff, 2002). Van Wyk and Boshof (2004) in his research also proved the difference score (EAO) owned by individuals from two groups of different professions: pharmacists and accountants.

In general, the measurement of EAO has similarities with the measurement of entrepreneurial characteristics which include innovation, need for achievement, locus of control, risk taking propensity, tolerance for ambiguity, and self confidence. Thus, we can derive an analogy that existing studies that prove differences in EAO from various professions is an indication of different entrepreneurial characteristics in individuals from various professions.

Based on the above literature reviews, the hypothesis proposed in this study are as follows:

Hypothesis 1: There are significant differences in the average value of innovativeness amongst entrepreneurs, private employees, government employees and police officers.

Hypothesis 2: There are significant differences in the average value of need for achievement amongst entrepreneurs, private employees, government 
employees and police officers.

Hypothesis 3: There are significant differences in the average value of locus of control amongst entrepreneurs, private employees, government employees and police officers.

Hypothesis 4: There are significant differences in the average value of risk taking propensity amongst entrepreneurs, private employees, government employees and police officers.

Hypothesis 5: There are significant differences in the average value of tolerance for ambiguity amongst entrepreneurs, private employees, government employees and police officers.

Hypothesis 6: There are significant differences in the average value of self confidence amongst entrepreneurs, private employees, government employees and police officers.

\section{RESEARCH METHOD}

The research samples were members of the Indonesian National Police, private employees, government employees, and entrepreneurs who lived and or worked in major cities in Indonesia. Surveys using a questionnaire developed from previous researches (Gurol \& Atsan, 2006; Koh, 1996) were done during April 2012 - March 2013.

To determine the validity and reliability of the instrument, we conducted statistical tests of factor analysis. Keiser-Meyer Olkin (KMO) score requirement is above 0.500 while the value of Barlett's Test of Spherity should be less than 0.05 . Total Variance Explained must have a cumulative value which is required, i.e., greater than $60 \%$, and the value of the Anti-image Matrix with the sign "a" required is above 0.500 . The value of Factor Loading of Component Matrix must be greater than or equal to 0.400 .

Further testing used to test whether there was a difference between entrepreneurial characteristics of the groups was done using ANOVA and the data processing was performed using IBM SPSS Statistics software version 21 .

\section{RESULT AND DISCUSSION}

Before testing the hypotheses, first we conducted validity and reliability testing. The results of this test showed that every statement in the questionnaire is valid and reliable. Surveys were done separately in four professional groups: police officers, government employees, private employees, and entrepreneurs in the major cities in Indonesia. There were 269 respondents who completed the questionnaire in the survey. Table 1 shows demographic characteristics of respondents by profession and gender.

Table 1. Respondents' Demographic Characteristic

\begin{tabular}{llccc}
\hline & & \multicolumn{2}{c}{ Gender } & \\
\cline { 3 - 4 } & & Male & Female & \\
\hline \multirow{2}{*}{ Profession } & Entrepreneurs & 40 & 60 & 100 \\
& Private Employees & 34 & 26 & 60 \\
& Government & 32 & 15 & 47 \\
& Employees & & & \\
Total & Police Officers & 62 & 0 & 62 \\
& & 168 & 101 & 269
\end{tabular}

We began the analysis with the test of homogeneity of variance in four groups of respondents using Levene Test of Homogeneity Variances. From the value of Levene test for each entrepreneurial characteristic (innovativeness, need for achievement, locus of control, risk taking propensity, tolerance for ambiguity, and self confidence) of the four groups of respondents, we can see that all of the probability value is below 0.05 . Therefore, it can be concluded that there is no difference in the variance of the four groups of respondents in this study. Table 2 shows the summary values of homogeneity test for all four groups of respondents.

Table 2. Test of Homogeneity of Variances

\begin{tabular}{lcccc}
\hline & Levene Statistic & df1 & df2 & Sig. \\
\hline Innovativeness & 14.754 & 3 & 265 & .000 \\
Need for achievement & 31.359 & 3 & 265 & .000 \\
Locus of control & 16.691 & 3 & 265 & .000 \\
Risk taking propensity & 15.742 & 3 & 265 & .000 \\
Tolerance for ambiguity & 14.395 & 3 & 265 & .000 \\
Self confidence & 14.559 & 3 & 265 & .000
\end{tabular}

Finding that there was no difference of variance between groups, we then proceeded to the subsequent analysis of research hypothesis testing 
by examining the significancy of $\mathrm{F}$ count value. The summary of the $\mathrm{F}$ value for each entrepreneurial characteristic is presented in Table 3.
From the value of $\mathrm{F}$ it can be seen that all of the characteristics have a probability value $<0.05$. Thus, it can be concluded that all the proposed

Table 3. ANOVA

\begin{tabular}{|c|c|c|c|c|c|c|}
\hline & & Sum of Squares & $\mathrm{df}$ & Mean Square & $\mathrm{F}$ & Sig. \\
\hline \multirow[t]{3}{*}{ Innovativeness } & Between Groups & 59.271 & 3 & 19.757 & 69.306 & .000 \\
\hline & Within Groups & 75.543 & 265 & .285 & & \\
\hline & Total & 134.814 & 268 & & & \\
\hline \multirow[t]{3}{*}{ Need for achievement } & Between Groups & 28.742 & 3 & 9.581 & 40.839 & .000 \\
\hline & Within Groups & 62.168 & 265 & .235 & & \\
\hline & Total & 90.911 & 268 & & & \\
\hline \multirow{3}{*}{ Locus of control } & Between Groups & 22.060 & 3 & 7.353 & 22.835 & .000 \\
\hline & Within Groups & 85.335 & 265 & .322 & & \\
\hline & Total & 107.394 & 268 & & & \\
\hline \multirow[t]{3}{*}{ Risk taking propensity } & Between Groups & 21.282 & 3 & 7.094 & 25.334 & .000 \\
\hline & Within Groups & 74.205 & 265 & .280 & & \\
\hline & Total & 95.487 & 268 & & & \\
\hline \multirow[t]{3}{*}{ Tolerance for ambiguity } & Between Groups & 33.173 & 3 & 11.058 & 41.904 & .000 \\
\hline & Within Groups & 69.930 & 265 & .264 & & \\
\hline & Total & 103.103 & 268 & & & \\
\hline \multirow[t]{3}{*}{ Self confidence } & Between Groups & 36.462 & 3 & 12.154 & 37.741 & .000 \\
\hline & Within Groups & 85.341 & 265 & .322 & & \\
\hline & Total & 121.803 & 268 & & & \\
\hline
\end{tabular}

Table 4. Significance of Multiple Comparisons of Entrepreneurial Characteristics

\begin{tabular}{|c|c|c|c|c|}
\hline & Entrepreneurs & Private Employees & Government employees & Police Officers \\
\hline $\begin{array}{l}\text { Innovativeness } \\
\text { Entrepreneurs } \\
\text { Private Employees } \\
\text { Government employees } \\
\text { Police Officers }\end{array}$ & $\begin{array}{l}-- \\
0.000 \\
0.000 \\
0.157\end{array}$ & $\begin{array}{l}0.000 \\
-- \\
0.020 \\
0.000\end{array}$ & $\begin{array}{l}0.000 \\
0.020 \\
-- \\
0.000\end{array}$ & $\begin{array}{l}0.157 \\
0.000 \\
0.000 \\
--\end{array}$ \\
\hline $\begin{array}{l}\text { Need for Achievement } \\
\text { Entrepreneurs } \\
\text { Private Employees } \\
\text { Government employees } \\
\text { Police Officers }\end{array}$ & $\begin{array}{l}-- \\
0.000 \\
0.000 \\
0.000\end{array}$ & $\begin{array}{l}0.000 \\
-- \\
1.000 \\
0.000\end{array}$ & $\begin{array}{l}0.000 \\
1.000 \\
-- \\
0.000\end{array}$ & $\begin{array}{l}0.000 \\
0.000 \\
0.000 \\
--\end{array}$ \\
\hline $\begin{array}{l}\text { Locus of Control } \\
\text { Entrepreneurs } \\
\text { Private Employees } \\
\text { Government employees } \\
\text { Police Officers }\end{array}$ & $\begin{array}{l}-- \\
0.000 \\
0.000 \\
0.293\end{array}$ & $\begin{array}{l}0.000 \\
-- \\
0.737 \\
0.000\end{array}$ & $\begin{array}{l}0.000 \\
0.737 \\
-- \\
0.000\end{array}$ & $\begin{array}{l}0.293 \\
0.000 \\
0.000 \\
--\end{array}$ \\
\hline $\begin{array}{l}\text { Risk Taking Propensity } \\
\text { Entrepreneurs } \\
\text { Private Employees } \\
\text { Government employees } \\
\text { Police Officers }\end{array}$ & $\begin{array}{l}-- \\
0.000 \\
0.000 \\
0.361\end{array}$ & $\begin{array}{l}0.000 \\
-- \\
0.341 \\
0.000\end{array}$ & $\begin{array}{l}0.000 \\
0.341 \\
-- \\
0.000\end{array}$ & $\begin{array}{l}0.361 \\
0.000 \\
0.000 \\
--\end{array}$ \\
\hline $\begin{array}{l}\text { Tolerance for Ambiguity } \\
\text { Entrepreneurs } \\
\text { Private Employees } \\
\text { Government employees } \\
\text { Police Officers }\end{array}$ & $\begin{array}{l}-- \\
0.000 \\
0.000 \\
0.000\end{array}$ & $\begin{array}{l}0.000 \\
-- \\
0.885 \\
0.000\end{array}$ & $\begin{array}{l}0.000 \\
0.885 \\
-- \\
0.000\end{array}$ & $\begin{array}{l}0.000 \\
0.000 \\
0.000 \\
--\end{array}$ \\
\hline $\begin{array}{l}\text { Self Confidence } \\
\text { Entrepreneurs } \\
\text { Private Employees } \\
\text { Government employees } \\
\text { Police Officers }\end{array}$ & $\begin{array}{l}-- \\
0.000 \\
0.000 \\
0.003\end{array}$ & $\begin{array}{l}0.000 \\
-- \\
0.989 \\
0.000\end{array}$ & $\begin{array}{l}0.000 \\
0.989 \\
-- \\
0.000\end{array}$ & $\begin{array}{l}0.030 \\
0.000 \\
0.000 \\
--\end{array}$ \\
\hline
\end{tabular}


hypotheses in this research were supported by the data. It means, statistically, there is at least one pair of significant average difference in terms of entrepreneurial characteristics within the four groups.

It is important to know further, which groups have the difference in average characteristics of entrepreneurial and which groups do not have differences in average of entrepreneurial characteristics. We then conducted an analysis of the post-hoc Tukey test. The results of these tests indicate different conditions for each of entrepreneurial characteristics as presented in Table 4.

We found that there were no significant differences in average of group of entrepreneurs and police officers in the characteristics of innovativeness, locus of control and risk-taking propensity. There was also no significant difference in the need for achievement, locus of control, risk taking propensity, tolerance for ambiguity, and selfconfidence between government employees and private employees.

\section{DISCUSSION}

Based on the results of the hypothesis testing at the previous section, we can conclude that all hypothesis is supported by statistics. We proposed that there will be significant differences in the specific entrepreneurial characteristics of individuals who are entrepreneurs and those who are not. This study corroborates previous studies (Gurol \& Atsan, 2006; Van Wyk and Boshoff, 2004; Kruger, Van Wyk \& Boshoff, 2002; Hoole \& Boshoff, 1997; Koh, 1996; Boshoff \& Scholtz, 1995), which claimed the evidence of specific characteristics that distinguish entrepreneurs from non-entrepreneurs.

By comparing the average value of the characteristics of entrepreneurial in four different groups of professional: entrepreneurs, government employees, private employees, and police officers, the results of this study theoretically strengthen and extend previous studies related to the topic of the characteristics of entrepreneurial and other types of profession. The differences in the average value of entrepreneurial characteristics might be caused by the organizational culture embedded in each of the profession environment (Singh, Pathak, Shee, Kazmi, \& Parker, 2013; Alstete 2008, Greenfield, 2000).

Developing entrepreneurial characteristics can be helpful for non-entrepreneurs who want to earn a living after retirement. The findings also show that individuals from the group of police officers have the highest average value on all the characteristics of entrepreneurs. This means that we can focus on developing entrepreneurial skills of these professionals. No significant differences in the average characteristics of entrepreneurs between government employees and private employees proved that in general these two groups of employees have the same opportunities in developing entrepreneurial characteristics.

Practical implications of this research can be used as consideration in developing employee development training in various groups of professions, especially police officers, government employees and private employees. Police officers are shown to have similar entrepreneurial characteristics with entrepreneurs. This evidence raises the importance of developing entrepreneurial skills within this group as an important skill that can be used after they retire. Entrepreneurial expertise can be valuable to start entrepreneurial activities, such as starting a new business or engaging in business activities with others. Entrepreneurship trainings can also be done in groups of government employees and private employees during retirement preparation.

The development of entrepreneurial characteristics are also important for employees who are still actively working, either government employees or private employees. Employees who have entrepreneurial characteristics can help improve the performance of the company as a whole, as described in the corporate entrepreneurship concept. Corporate entrepreneurship can boost competitiveness, growth, and profitability of a company (Zahra, Kuratko, and Jennings, 1999; 
Brazeal, 1993; Zahra, 1991; Kanter, 1985). Therefore, employees with entrepreneurial characteristics are an essential resource for a company growth.

\section{CONCLUSION AND SUGGESTION}

Research objectives are to prove wether there are differences in the average value of entrepreneurial characteristics of individuals who belong to a group of entrepreneurs and non-entrepreneurs (police officers, government employees, private employees). The study shows significant differences in the characteristics of innovativeness in individuals who belong to a group of entrepreneurs and non-entrepreneurs (police officers, government employees, private employees). There are also significant differences in other entrepreneurial characteristics: need for achievement, locus of control, risk taking propensity, tolerance for ambiguity, as well as self confidence.

Individuals from police officers group were found to have the highest average value of entrepreneurial characteristics compared to other professionals. However, we found no significant differences in the average value of the entrepreneurial characteristics between individuals from the group of government employees and private employees.

Several suggestions can be drawn from the research results. There are previous studies that prove there is a link between the culture of the organization with the entrepreneurial characteristics of employees and the company's overall performance. Therefore, further researches need to be done to look at the possibility of interaction between organizational culture of each group profession with entrepreneurial characteristics possessed by individuals in the group.

This study found that police officers have the highest entrepreneurial characteristics among other groups. Further researches are then needed to determine what type of businesses that fit individuals from this groups.

\section{REFERE N C ES}

Alstete, J.W. (2008). Aspects of entrepreneurial success. Journal of Small Business and Enterprise Development, 15(3), 584-594.

Boshoff, A.B. \& Scholtz, C.P.T. (1995). Measuring attitudes as a way of differentiating entrepreneurs', South African Journal of Economic and Management Sciences, 16, 1-11.

Brazeal, D.V. (1993), Organizing for internally developed corporate ventures. Journal of Business Venturing, $8(1), 75-90$.

Entrialgo, M., FernaÂndez, E. and VaÂzquez, C.J. (2000). Psychological characteristics and process: the role of entrepreneurship in Spanish SMEs. European Journal of Innovation Management, 3(3), 137-149.

Greenfield, P. (2000). Three approaches to the psychology of culture: where do they come from? Where can they go? Asian Journal of Social Psychology, 3(3), pp. 223-240.

Gurol, Y., Atsan, N. (2006). Entrepreneurial characteristics amongs university students. Some insights for entrepreneurship education and training in Turkey. Education and Training, 48(1), 25-38.

Hansemark, O.C. (1998). The effects of an entrepreneurship programme on need for achievement and locus of control of reinforcement. International Journal of Entrepreneurial Behavior \& Research, 4(1), 28-50.

Hisrich, R.D., Peters, M.P., and Shepherd, D.A. (2012). Entrepreneurship (9th ed). New York: McGraw Hill. 
Ho, T.S. and Koh, H.C. (1992). Differences in psychological characteristics between entrepreneurially inclined and non-entrepreneurially inclined accounting graduates in Singapore. Entrepreneurship, Innovation and Change: An International Journal, 1, 43-54.

Hoole, C., Boshoff, A.B. (1997). Measurement qualities of the entrepreneurial attitude orientation scale when used inter-culturally. South African Journal of Economic and Management Sciences, 21, 1-25.

Kanter, R.M. (1985). Supporting innovation and venture development in established companies. Journal of Business Venturing, 1(1), 47-60.

Koh, H.C. (1996). Testing hypotheses of entrepreneurial characteristics. Journal of Managerial Psychology, 11(3), 12-25.

Korunka, C., Frank, H., Luegler, M., Mugler, J. (2003). The entrepreneurial personality in the context of resources, environment and the start-up process: A configurational approach, Entrepreneurship: Theory and Practice, 28, 23-42.

Kruger, B.J., Van Wyk, R. \& Boshoff, A.B. (2002). Entrepreneurial attitudes in different occupational and organizational groupings. Article submitted to the Journal of the Southern Africa Institute for Management Scientists.

Louw, L., van Eeden, S.M., Bosch, J.K., Venter, D.J.L. (2003). Entrepreneurial traits of undergraduate students at selected South African tertiary institutions. International Journal of Entrepreneurial Behaviour \& Research, 9(1), 5-26.

Robinson, P.B., Stimpson, D.V., Heufner, J.C. \& Hunt, K.N. (1991). An attitude approach to the prediction of entrepreneurship. Entrepreneurship: Theory and Practice, 15(4),13-31.

Sarri, K., Trihopoulou, A. (2005). Female entrepreneurs' personal characteristics and motivation: a review of the Greek situation. Women in Management Review, 20(1), 24-36.

Singh, S., Pathak, R.D., Shee, H., Kazmi, A., Parker, D. (2013). Interplay between entrepreneurial characteristics, organisational structure, corporate culture and SME performance: empirical results from Fiji Islands. Int. J. Entrepreneurship and Small Business, 18(2), 229-246.

Thompson, J.L. (2004). The facets of the entrepreneur: identifying entrepreneurial potential. Management Decision, 42(2), $243-258$.

Van Wyk, R., \& Boshoff, A. B. (2004). Entrepreneurial attitudes: A distinction between two professional groups. South African Journal of Business Management, 35(2), 33-38.

Yusof, M., Sandhu, M.S., and Jain, K.K. (2007). Relationship between psychological characteristics and entrepreneurial inclination: A case study of students at University Tun Abdul Razak (UNITAR). Journal of Asia Entrepreneurship and Sustainability, 3(2).

Zahra, S. A. (1991). Predictors and financial outcomes of corporate entrepreneurship: an exploratory study. Journal of Business Venturing, 6(4), 259-285.

Zahra, S. A., Kuratko, D. F., and Jennings, D. F. (1999). Guest Editorial: Entrepreneurship and the acquisition of dynamic organizational capabilities. Entrepreneurship Theory and Practice, 24(1), 5-10. 